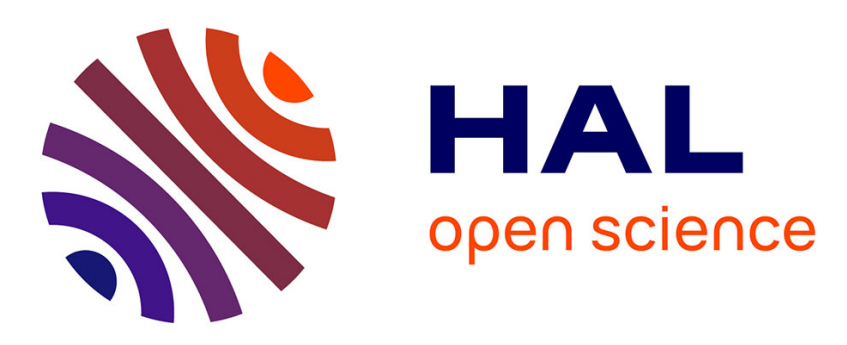

\title{
Characterising the Industrial Context of Engineering Change Management
}

Antti Pulkkinen, Petri Huhtala, Simo-Pekka Leino, Juha-Pekka Anttila, Ville V. Vainio

\section{- To cite this version:}

Antti Pulkkinen, Petri Huhtala, Simo-Pekka Leino, Juha-Pekka Anttila, Ville V. Vainio. Characterising the Industrial Context of Engineering Change Management. 12th IFIP International Conference on Product Lifecycle Management (PLM), Oct 2015, Doha, Qatar. pp.618-627, 10.1007/978-3-31933111-9_56 . hal-01377490

\section{HAL Id: hal-01377490 \\ https://hal.inria.fr/hal-01377490}

Submitted on 7 Oct 2016

HAL is a multi-disciplinary open access archive for the deposit and dissemination of scientific research documents, whether they are published or not. The documents may come from teaching and research institutions in France or abroad, or from public or private research centers.
L'archive ouverte pluridisciplinaire HAL, est destinée au dépôt et à la diffusion de documents scientifiques de niveau recherche, publiés ou non, émanant des établissements d'enseignement et de recherche français ou étrangers, des laboratoires publics ou privés.

\section{(c)(1)}

Distributed under a Creative Commons Attribution| 4.0 International License 


\title{
Characterising the Industrial Context of Engineering Change Management
}

\author{
Antti Pulkkinen ${ }^{1}$, Petri Huhtala ${ }^{1}$, Simo-Pekka Leino ${ }^{2}$, \\ Juha-Pekka Anttila ${ }^{2}$, Ville V. Vainio ${ }^{1}$ \\ ${ }^{1}$ Department of Mechanical Engineering and Industrial Systems, Tampere University of \\ Technology, Tampere, Finland \\ firstname.lastname@tut.fi \\ ${ }^{2}$ VTT Research Center \\ First.Lastname@vtt.fi
}

\begin{abstract}
Engineering changes (EC) and their management (ECM) can be categorized from several points of view. In this paper an EC is mainly considered from the position in lifecycle of the object of change: NPD vs. serial production. The performance aspects of engineering change processes emphasize the balancing of speed of the processes and the communication and assessment of consequent changes. ECM practices are studied by comparing two case companies. The cases indicate ECM is highly related to the organization, history and strategy of a company. The increased efficiency in engineering changes is aspired by streamlined ECM in new product development, while enhanced ECM processes apparently batch ECs for increased overall effectivity. The mutual challenge for the studied companies is that the NPD projects result with a set of change requests for serial production.
\end{abstract}

Keywords: ECM, Case study, Comparison

\section{Introduction}

The engineering changes (ECs) have a large impact on life cycle processes. In this paper we study how companies manage engineering changes in the different kind of business context. We argue the selection or defining of suitable engineering change management (ECM) process is not a simple choice. Instead, the stage of lifecycle and the business context define the selection of suitable ECM process.

First, by analysing the literature on ECM we outline the characteristics of ECM. Then we study two case companies based on to the history and culture of a company, their position and set up in supply chain, personnel and strategy, organisation, size, co-location, product types and architectures, as well as the product lifecycle management (PLM) systems architecture and integration. We find these issues important for the research and the development of standards on ECM and suggest further directions for research and development of ECM for different stages of product life cycle and business context. 
We studied the practises of engineering change by comparing two companies. For the comparison we characterise the different factors we consider pertinent for the comparison. The data collected from the companies is based on long term collaboration as well as two separate benchmark site visits carried out in 2011 and 2014 in both of the companies. The significance of the findings is being discussed in the final chapter.

\section{Engineering change management}

Our intention is to emphasize the importance of the performance of making and managing changes. However, we first define the ECs in two categories and find a potential difference in the EC performance of the categories. Finally the conclusions and research questions are being presented.

\subsection{Defining engineering changes}

Huang and Mak [1] define ECs as modifications on the form, fit, material, dimensions or functions of product or item. According to Terwiesch and Loch [2] an EC is a modification to a component of a product, after the original design task has been completed. However, the changes may take place in product development or in production stage [3]. We propose the two types of changes,

I. ECs within product development projects or engineered to order (ETO) projects as project engineering changes ( $\mathrm{pECs}$ ).

II. ECs on the objects in repetitive, serial production as standard engineering changes (sECs).

The standard engineering changes may occur in mass production and mass customization. The sECs are targeted on the items of standard products or re-usable assets, such as modules. Both types of ECs are made on design documents and/or constituent elements within the product structures of different domains [4]. In a PLM system the object of change can be items and documents related to product lines or series, products, assemblies, modules, components, etc.

Generally, the reason is being specified with an engineering change request (ECR) that defines the object of change, the reason of change and plausible solution [1]. According to Clarkson et al. [5] an engineering change may be either emergent or initiated. Moreover, the content of ECR defines either the need of improvement (innovation orientation) or the failure of meeting specifications (problem orientation) in the previous revision of the design [6]. The engineering change management (ECM) functionality of a PLM system provides a selection from a set of reasons for change.

\subsection{Performance of engineering change management}

Generally, engineering design is considered as ill-defined activity, i.e. some of the design requirements are either initially unknown or will be subject to change during 
the course of design. The design of engineering change (EC) is a specific kind of design activity, where all the objectives of ECs are well defined with ECRs and the effect of EC can be well defined as a plausible solution.

The design performance is based on the efficiency of the design activity, which in turn is guided by the design activity management that largely defines the effectivity of the design result [7]. Similarly, the performance of engineering change process is the result of success in two activities: the actual making of engineering change and engineering change management (ECM). The effectiveness of each change is determined with an ECR. Thus, the performance of ECM relies on the effectivity of ECRs and change review board decisions as well as the efficiency of the rest of ECM process. Consequently, the engineering design of changes is more determined than design in general.

Following the classical efficiency measurement paradigm, the efficiency of EC processes can be controlled with three factors [8]:

- Number of active EC's

- Time taken to deal with EC

- Cost or effort needed to process an EC

Watts [9] emphasizes the cost considerations of changes and the speed of ECM process. The actual cost of an EC is much higher than the administrative cost of EC, because of the need to adopt changes in downstream phases such as manufacturing and procurement. For each change a defined business case should exist and documented with a PLM system. For calculating the business case the rules have to be laid out by the top management of an organisation [9].

However, calculating precise factors may not be absolutely necessary or even preferable. Clark and Fujimoto [10] compared engineering changes in Japanese and Western manufacturing companies. According to them, the differences in approach lie not in numbers, but in patterns and content. They also advised fast implementation instead of bureaucratic norms. Also, the type of business has an effect on the number of changes [4] and the cost of change is relative to the stage of product life-cycle [10, 11]. The front loading of changes is typically a better approach than postponing them until the manufacturing stage. This indicates the number of $\mathrm{pECs}$ should be higher than the number of sECs. The prevention of changes from emerging decreases the cost of changes likewise to the integration of parts decrease the cost of assembly what does not exist, will not cause life cycle costs downstream to development.

\subsection{Characterizing ECM}

There appears to be several attributes to characterize ECM in a company. Among these attributes are the application of ECM and the depth of change assessment and management. The application of ECM can be further decomposed into several questions. What does ECM stand for in an organization? How the organization has adopted ECM? Does ECM rely on personal communication or is it supported with a computerized system, such as PDM system? The depth of change assessment and management deals with the effect of change and its communication throughout the organizations carrying out downstream activities. 
The assessment can measure the effect of change on product portfolio and/or product families as well as product and production processes, including supply. On top of the assessment the co-ordination of change effectivity and compatibility are vital issues for stakeholders, e.g. supply network. Thus, co-ordination, communication and configuration management processes are inevitable attributes of ECM. The attributes can be considered as the levels of ECM maturity as indicated in the first row of table 1 . However, we withhold of making any preferences on whether any of the attributes or levels is better than other one. Concurrent step-by-step progress on each level is a stereotypical situation, which may not be found in a company. We expect that in most cases the situation is the combination of attributes in different level.

Table 1. Attributes characterizing ECM

\begin{tabular}{|c|c|c|c|c|}
\hline Attribute & 0 & 1 & 2 & 3 \\
\hline Application, what & $\begin{array}{l}\text { Ad-hoc } \\
\text { procedures }\end{array}$ & $\begin{array}{l}\text { Standard process } \\
\text { Out of the box }\end{array}$ & $\begin{array}{l}\text { Applied to the } \\
\text { needs of } \\
\text { stakeholders }\end{array}$ & $\begin{array}{l}\text { Justified and } \\
\text { measurable }\end{array}$ \\
\hline Application, how & $\begin{array}{l}\text { No common } \\
\text { understanding }\end{array}$ & $\begin{array}{l}\text { Departmental } \\
\text { ECM process }\end{array}$ & $\begin{array}{l}\text { Site specific } \\
\text { ECM processes }\end{array}$ & $\begin{array}{l}\text { Company-wide } \\
\text { ECM process }\end{array}$ \\
\hline $\begin{array}{l}\text { Communication } \\
\text { and Co-ordination }\end{array}$ & $\begin{array}{l}\text { Blind changes } \\
\text { (no ECRs, ECOs } \\
\text { or ECNs) }\end{array}$ & $\begin{array}{l}\text { According } \\
\text { processes (1-way } \\
\text { communication, } \\
\text { such as bulletin) }\end{array}$ & $\begin{array}{l}\text { Improved } \\
\text { processes (2-way } \\
\text { communication), } \\
\text { impact analysis } \\
\text { on processes }\end{array}$ & $\begin{array}{l}\text { Enhanced } \\
\text { process } \\
\text { (collaboration), } \\
\text { impact } \\
\text { controlled }\end{array}$ \\
\hline Configuration & $\begin{array}{l}\text { Singular changes } \\
\text { (compatibility } \\
\text { case by case) }\end{array}$ & $\begin{array}{l}\text { Revision } \\
\text { management, } \\
\text { change impact } \\
\text { analysis on } \\
\text { product } \\
\text { structures }\end{array}$ & $\begin{array}{l}\text { Release practices } \\
\text { incorporated, } \\
\text { impact } \\
\text { assessment on } \\
\text { product portfolio }\end{array}$ & $\begin{array}{l}\text { Totally Planned } \\
\text { Changes }\end{array}$ \\
\hline
\end{tabular}

In a stereotypical situation " 0 " there is no formal change process in a company, but each EC is managed separately, without a pre-defined procedure. The organization and responsibilities related to ECM cannot occur, because of the presence of idiosyncratic procedures and ad hoc applications. The changes are communicated informally and their relation to product or processes remains unstudied. A first step to formal ECM process (level 1) addresses on singular items and documents with a bottom up approach. The process is given as a rule from management without taking a wider point of view or consideration of timing aspect of changes. The impact of change is assessed by the affected product structure (Bill of Material), which can be automatically studied. ECM is a federated approach where changes are considered by an experienced review board that is trusted to consider all the relevant aspects.

One step beyond (level 2) is a configuration oriented CM, which involves the consideration of an EC as part of of larger set up such as module, product and or product families as well as the batching of changes in time in the form of releases. The changes may take place with a site level application (e.g. effectivity of changes may vary between different production sites). The most advanced - but also the heaviest ECM process - can be termed as the coordinated enterprise CM process that 
includes company-wide, collaborative ECM along with configuration management that allows the planning of changes in advance in contrast to reactive manner of the " 0 " and "1" approaches. The steps of ECM development can be characterized as changes in attributes, e.g. from attributes in level 0 to level 1 or from 1 to 2 , etc.

Level 1 ECM defines the effect of change by either rejecting or approving the change. Configuration Management (CM) is an approach of the levels 2 and 3 and it includes another managerial choice in the form of postponing the effectivity of change by using release packages. Most known examples of this come from software engineering and car industry in the form of service packs and facelifts.

\subsection{Concluding literature review and research question}

Based on the versatility of characteristics, it is difficult to give valid academic solution to question how to manage engineering changes in a specific company. However, the more the company develops ECM (higher rankings in Table 1) the more it is concerned about the effectivity of EC process, e.g. the prioritizing ECRs, assessing their impact and communicating ECs. Increased efficiency in the actual engineering of changes may be aspired with the less complex ECM processes. Apparently, the more complex ECM process (levels 2 and 3) is plausible with the case of serial production than with low volume production or with one-of-a kind projects. In different kind of business there are certainly the different amounts of resources to devote on ECM and selecting right ECM for certain business is not a simple issue.

Literature appears to suggest two different kinds of approach to enhance the performance of engineering changes. Ideal change management procedures should be either preventing changes, lean and streamlined, fast and non-bureaucratic or calculative, cost oriented approaches with an effective change review board at the center of ECM process. In this paper, the first approach is termed as lean ECM and the latter as enhanced ECM. An indicator of the difference of the approaches is the speed of change. The lean approaches propose fast and early delivery of changes and the enhanced ECM advocate the postponing of changes to release packages. Should one of the approaches be chosen and used for every situation or can a company use the both of the approaches that appear to be mutually exclusive?

\section{The research material and method}

We approach the question above with a comparative case study, where material has been collected by benchmarking site visits [12] and three collaboration projects. The timeline of the material collection is long, e.g. two initial benchmarking site visits took place in 2011 and 2012 and the latter two visits took place in 2014. Also, the authors of this article have been managing or carrying out or several case studies during the past years ranging from surveys to instructing M.Sc. and Ph.D. theses as well as joint development projects.

During the course of research several issues were being addressed by the personnel of the case companies. All of these issues could not have been foreseen by the researchers and so the utilizing of pre-planned questionnaires and forms were omitted. 
Our previous experience on the approach was that the discussion of experts with different backgrounds provided new ideas and subsequent questions. Thus, the site visits and other meetings were semi-structured with prepared agenda and in three visits audio recording and transcription were used as a means of collecting the data.

The qualitative comparative analysis requires a frame $[13,14]$, which we have test in an earlier study. However, the process of building up the frame for such kind of purpose is tedious and time consuming. Instead, we compare the key issues found out in the data collection. We argue that with only two cases to study the less formal approach is valid.

\section{Findings and analysis}

The studied case companies have a lot in common as they are both selling configurable mobile machinery for global markets. In this article, the companies and products are codified as companies A and B. In both of the companies there have been large product development projects during the past years. Both companies are the key players in niche markets, i.e. within top 3 with most of their product lines. Thus, the products are rather expensive investment goods with a very limited annual volume. Also, the lifespan of the products is long in both companies, they have facilitated take-back business, service business is increasingly important for both of them and, therefore, PLM is one of the key issues in company strategies.

\subsection{History and overall characteristics of the companies}

One of the main differences of the companies is their size, background and culture. The company A is part of larger corporation and the company $\mathrm{B}$ is an independent company. The corporation consisting of three business areas is roughly nine times larger in turnover and personnel in comparison to company B.

The company A has century old history, which contains many branches to new businesses and organizations. The limited company has been an active in a number of mergers mostly internationally and it has several sales and service offices as well as manufacturing sites in Europe, Asia, North and South America. Also the engineering and supply network of the company is truly global. On the average the engineers stay within the company for few years. In company A the use of outsourced engineering resources is common. The annual volume of the products taken into study is few hundreds and varies from few to few dozens of sold units / product line. Thus, formal processes are a precondition for the operation of the company A.

On the contrary the company B has a 40 year old history with a very limited number of mergers, where the company has been the host of merger. For most of its history it has been (and currently is) a family owned company, which has international sales and service offices. As opposed to trend of outsourcing component manufacturing and relying on global supply chains and assembly sites, the majority $(90 \%)$ of the suppliers of the company B are situated in the same country where the company's own manufacturing site is located. Recently, the company has also insourced the manufacturing of the key components and main component suppliers 
reside close to the company. Engineering is done within one office and the company relies on the in-house engineering personnel with long experience in the company $\mathrm{B}$. Thus, all the processes and functions of the company B are within arms-length of each other and heavy formalism is not required for the operation of the company.

\subsection{IT support, processes and organizations}

In the company A the formal use of IT supported processes appears to be the case in product development. One indicator of this is the strong link between CAD and Engineering Data Management (EDM) system, one-way information flow from EDM to the formal PDM system and furthermore to Enterprise Resource System (ERP), where the configuration rules are being made. During the recent years the migration and consolidation of ERP system has been the largest IT project for the company A. The number of users increases along with the steps of information exchange between federated systems, while communication is based on systems integration. Product development process is an application of stage-gate model and it is controlled by product managers who may not have engineering background. Prototypes and 0 -series production were being produced, while all the products are sold to customers. Procurement uses the same system for both the prototypes and serial production.

In the company $\mathrm{B}$, each member of an organization has a clearly defined role and a software environment where to contribute to an engineering process. Product development is carried out by an autonomous team with a consecutive process. It begins with drafts laid out with separate CAD software, followed by detailed engineering and set-based approach where the overall concept is concretized with the same CAD and product data is structured into PDM software. In this process the items are created and module compatibilities are defined. The compatibility of modules and items, i.e. the configuration rules, is being modelled with MS Excel. There are models for each product sections, which are treated as modular sub-products. These can be sold separately, while a configuration model of higher level controls the compatibility of the overall product configuration. Finally, the detailed items of the prototype products can be procured and assembly sequences planned. The procurement of prototype items is separate from serial production and often the last minute changes are handed over from engineering to procurement with a bi-directional and informal communication channel. For the suppliers of serial production the company has provided a limited access to internal systems, such as PDM and ERP.

The sales process in both companies is supported with captured product configuration knowledge. The sources and models for these are different as the company $\mathrm{A}$ is using the specific functionality of its ERP system for product configuration, but the company B does not utilize this kind of setting. However, both companies have modelled and represented their configuration knowledge with MS Excel as presented above. Instead, the updating of the configuration knowledge is different. 


\subsection{The characteristics of ECM in companies}

There are similarities in the overall performance of ECs within the companies with slight differences. The companies were reluctant to reveal the cost information related with ECs. The average throughput time of ECs in the company B was faster than in the company A, which had large variety in the handling of ECs. Both companies had almost the same volume of ECs with product development projects as well as the annual backlog of ECs was comparable.

Actually, both companies have the same PDM system, but their use of the system is slightly different. The system is capable of representing many aspects of engineering change management, such as several attributes for validating the ECR from various different reasons and points of view, structuring the revised item or document within product portfolio and families as well as functions for the impact analysis of an EC, deriving a set of notifications and integrations for different systems such as CAD, EDM and ERP systems. The company A utilizes the functionality of the system to greater extent than the company B, which has adopted the basic ECM process with some add-on functionalities especially with the items of serial procurement (to differentiate the case we call them SECM). Both companies reported about the same number of sECs annually as well as when allocated on new product development projects (pECs in NPD). However, the company B has slightly faster (about $10-15 \%$ ) cycle time in processing sECs than company A. The company A analyzed the changes to reside in three categories: fast, normal and indefinite. The fast changes can be processed within days, the normal ECs take weeks (by maximum) and the indefinite sECs are the historical backlog that has not been processed, because of the characteristics of the ECRs. Both companies indicated the drive towards batching the sECRs into larger development or change sets. Recently, company A has adopted the CMII process in ECM and it has indicated to be effective in improving the efficiency of ECM processes. Also company B has batched the sECRs as a year model changes.

In company A the effectivity of revisions has to be planned along with estimated sales volume. In company B the revisions are fully compatible with each other. Thus, there is no need to the strict planning of the effectivity of revision changes, because the modular product structures allow certain flexibility in sales, supply and manufacturing. In the case of non-critical change, the functions may take into use the revision based on their stock levels. In company A this is not the case, but the different sites have to plan the use of revisions in advance.

In company A the ERP system as well as the supply network are global and they are also mostly the same for projects and serial production. Thus, the procurement procedures of NPD project items as well as SECM and pECM processes are similar in the company A. The effect of this is that sometimes all the required ECs cannot be incorporated in the prototypes due to lead time in supply. This is especially problematic, if a batch is being ordered without knowing if the item of procurement is a part of a project or component for serial production. The ECM or the supply may be seen too slow in comparison to engineering in new product development. As a consequence a large number of ECRs follow the NPD project, which can be seen as a problem. 
Because the key suppliers of company B are within arms-length, the feedback in projects is enabled and plausible. This makes the pECM process integrated and informal in company $\mathrm{B}$, where the engineers often negotiate with procurement or even with suppliers about the possibility of having an improved revision in a prototype. The throughput time of the new product development projects in company B have been very fast - from concept to prototype in few months. This is outstanding when the type of business and the product technology (mechatronics in mobile machinery) are taken into consideration. However, also the company B reported that a large number of ECs has been induced by each NPD project.

In company A the throughput time of project ECs is often longer than the cycle time in product development, which is not the case in company B. In practice, this means the requested changes may not have been designed for the prototype part supply even though they have been requested before procurement. In company B the requested changes are typically designed and released before the procurement is done. So, supplied parts are usually manufactured according to the latest design revisions. Thus, there are differences in ECM, procurement as well as in supply network between the benchmarked companies, which lead to different kind of performance of product development projects.

\section{Conclusions}

Engineering change management (ECM) was studied with a selected review on literature and a comparison of two case companies. A set of attributes and their values were being presented to highlight the variety of potential approaches in ECM. Two drivers for ECM were being recognized: the need for early and timely actions in ECM as well as the proper assessment and evaluation of engineering change requests (ECR) included in advanced CM based ECM. Also, the position of an ECR in the lifecycle of the object of change was highlighted by having separate concepts for the ECs of new product development (NPD) project and standardized serial production: $\mathrm{pEC}$ and sEC.

ECM is a topic related to the characteristic of an organization, such as the history, organizational structures and strategy of a company. It is also affected by the networking and product structuring principles a company has adopted. For ECM support the global, outsourced engineering and manufacturing functions set higher demands than local in-house engineering and arms-length supply network. However, the less tedious and straightforward ECM procedures along with the collaboration with agile supply and engineering network appear to pay of better than the in depth analysis and full PLM support in NPD. Thus, the emphasis is on enhanced ECM processes on objects of serial production and increased change efficiency in NPD. However, the two cases indicate the NPD projects do result in a large number of sECs, which is currently the challenge for research.

The reliability of the results is limited due to small number of cases. Also, the specific areas, e.g. the management of changes in product configuration knowledge, were not included. Our aim is to have a larger set of case studies as well as to focus on the omitted areas. 
Acknowledgments. We acknowledge the participants of the benchmarking, especially company representatives. We are also grateful for TEKES, the Finnish Funding Agency for Technology and Innovation, as well as the consortium of MANU and Fimecc, for supporting the research presented here.

\section{References}

1. Huang GQ, Mak KL. Current practices of engineering change management in UK manufacturing industries. International Journal of Operations \& Production Management,1999; 19: pp. 21-37.

2. Terwiesch, C. Loch, C.T. Managing the Process of Engineering Change Orders: The Case of the Climate Control System in Automobile Development. Journal of Product Innovation Management, 199; 16 pp. 160-172

3. Wright IC. A review of research into engineering change management: implications for product design. Design Studies 1997; 18(1): pp.33-42.

4. Pulkkinen A., Riitahuhta A. On the relation of business processes and engineering change management. In: The Proceedings of the International Conference on Product Lifecycle Management, PLM'09. Edited by McMahon C., Dutta D., Huang G. Inderscience Enterprises Ltd. 2009

5. Clarkson, J.P., Simons, C., and Eckert, C., Predicting change propagation in complex design. Journal of Mechanical Design, (2004) 126 (5), 788-798.

6. Lindemann U., Reichwald R. Integriertes Ärderungsmanagement. Springer Verlag. 1998. $341 \mathrm{pp}$.

7. O'Donnell, F.J., Duffy, A.H.B. Design Performance. Springer Verlag, London Ltd. 2005 (213pp.)

8. Huang GQ, Yee WY, Mak KL. Current practice of engineering change management in Hong Kong manufacturing industries. Journal of Materials Processing Technology, Volume 139, Issues 1-3, 20 August 2003, Pp. 481-487

9. Watts F.B. Engineering Documentation Control Handbook, Fourth Edition: Configuration Management and Product Lifecycle Management. William Andrew; $4^{\text {th }}$ edition (2011). 400 pp.

10.Clark K.B., Fujimoto T. Product development performance: strategy, organization and management in the world auto industry. Harvard Business School Press, Boston (1991). 432 pp.

11.Jarrat T.A.W., Eckert C.M., Caldwell N.H.M., Clarkson P.J. Engineering change: an overview and perspective on the literature. Research in Engineering Design (2011) 22: Pp. $103-124$

12.Pulkkinen A., Markova T., Rissanen N. Researching PLM process in industry - Case of Benchmarking ECM. In: The Proceedings of the International Conference on Product Lifecycle Management, PLM11. Edited by Pels H.J., Bouras A., McMahon C. Available at: http://www.phi-kpe.nl/ifip-working-group-5-1-34.html (accessed at 15th of June 2015)

13.Ragin C.C. The Comparative Method: Moving Beyond Qualitative and Quantitative Strategies. University of California Press $1987.218 \mathrm{pp}$.

14.Rissanen N., Pulkkinen A., Vainio V. Testing a Framework for Analyzing PLM Architecture in Global Manufacturing Companies. In: The Proceedings of the 22nd International Conference on Flexible Automation and Intelligent Manufacturing (FAIM 2012). Edited by Torvinen S. \& Nylund H. 